\title{
Influence of Different Packaging Materials on the Seed Quality Parameters of Chickpea
}

\author{
Jay V. Patel*, D.K. Antala and Abhay N. Dalsaniya \\ Department of Processing and Food Engineering, College of Agricultural Engineering and \\ Technology, Junagadh Agricultural University, Junagadh, Gujarat, India (362001) \\ *Corresponding author
}

\begin{tabular}{|l|}
\hline Ke y w o r d s \\
Chickpea grain, \\
Packaging \\
materials, Storage \\
life, Seed quality
\end{tabular}

\section{Introduction}

The chickpea (Cicer arietinum L.) is one of the most important pulse crop cultivated throughout the world. India is the largest chickpea producing country accounting for $72 \%$ of the global chickpea production. In India, the area under chickpea cultivation was 95.4 lakh ha with an annual production of 90.8 lakh tons during the year 2016-17 (Anon., 2017). It is a good source of carbohydrates, important vitamins, minerals, essential amino acids and nutritionally important unsaturated fatty acids. It is a major and cheap source of protein for millions of vegetarians in the developing countries. Chickpea is predominantly consumed in the form of whole grain, dhal, flour, sprouted grain, green or 
matured dry seeds and is used in the preparation of a variety of snacks, sweets and condiments (Jukanti et al., 2012).

Pulses are more difficult to store than cereals and suffer much greater damage from insects and microorganisms. The post-harvest losses of food grains are estimated to be 10 to $20 \%$ in India (Chahal, 2011). The pulse beetle and bruchids are mostly found during the storage of chickpea and reduces the market value of seed, germination percent and nutrition value which make chickpea unfit for marketing as well as human consumption (Modgil and Mehta, 1994).

Many synthetic insecticides have been found effective against this pest, but are hazardous and toxic, due to their residual effect in the food. Insect resistance to phosphine is a global issue now and control failures have been found in some countries. Methyl bromide has been identified as a major contributor to ozone depletion and is, therefore, being phased out completely (Taylor 1989). Proper packaging and storage methods are essential for good storage stability for food grains. Traditionally, jute has been used for bulk packaging of food grains and pulses. Plastic materials viz., HDPE and PP woven sacks, multi-layer co-extruded film, triple-layer bags and aluminium foil are used very widely for food grain and seed storage due to the excellent barrier to moisture, air, odors and microorganisms. Polyethylene lining in jute bag or in PP woven bag are also useful to protect the products from moisture ingress. Vacuum packaging increases storage life of food products by inhibiting the growth of microorganisms and improves hygiene by reducing the danger of cross contamination (Meena et al., 2017). Looking to the above facts, the present research work was undertaken to retain the quality and reduce post-harvest loss of the grain.

\section{Materials and Methods}

A storage experiment was carried out for a period of 12 months i.e. from May-2017 to April-2018 at Department of Processing and Food Engineering, College of Agricultural Engineering and Technology, Junagadh Agricultural University, Junagadh. The freshly harvest and uniformly matured desi chickpea grain $(G J G-3)$ was procured from the Agricultural Research Station, Dhari, JAU, Junagadh. The grain was cleaned and graded by cleaner-cum-grader machine. The grain was then cleaned and sorted out manually to remove extraneous materials such as dust, dirt, stones, chaff, immature grains, insect infested and damaged grains. The chickpea grain was dried for $6 \mathrm{~h}$ in open yard for sun drying up to $7.6 \%$ (w.b.) final moisture content for safe storage. The grains were packed in different packaging materials with $5.0 \mathrm{~kg}$ sample size. The jute bags, polyethylene lined jute bags and PP woven laminated bags were packed and sewed by portable stitching machine (Revo bag closer, Surat) after filling the grain. For PICS bags packaging, the grains were filled and sealed inner double layer HDPE bags and packed in outer PP bags and sewed by portable stitching machine. HDPE bags, multilayer coextruded plastic bags and polyethylene laminated aluminium foil bags were packed with vacuum $(700 \mathrm{~mm} \mathrm{Hg}$ ) in vacuum packaging machine (Packmech Engineers, Ahmedabad).All the bags were stored at the end of month of April, 2018 at room temperature $\left(13.2-38.5{ }^{\circ} \mathrm{C}, 18.8-91.1 \%\right.$ $\mathrm{RH})$ for twelve months on platform in the laboratory for rat control.

\section{Details of treatments}

\section{Independent parameters}

1. Jute bag (JB) (control)

2. Polyethylene lined jute bag (JBP)

3. PP woven laminated bag (PPL) 
4. HDPE bag with vacuum (HDPEV)

5. Multilayer coextruded plastic bag with vacuum (MCPV)

6. Polyethylene laminated aluminium foil bag with vacuum (ALPEV)

7. Perdue improve crop storage bag (PICS)

8. No. of Replications: 3 (Three)

9. Statistical Design: Completely Randomized Design (CRD)

All the seed quality parameters of the grains were recorded during two-month of storage by standard methods. The environmental parameters such as temperature and relative humidity were recorded daily with using data logger at room conditions in the laboratory during storage. Moisture contents of the samples were determined by using hot air oven method as suggested by Sadasivam and Manickam (1996).The insect population was recorded by taking500 $\mathrm{g}$ of sample for recording insect population like pulse beetle and bruchid. The total number of adults obtained from each sample was counted and recorded. Grain damage percentage was calculated by taking sample of 200 Nos. chickpea grains for counting damaged grains from the sample. The grain damage was determined using following formula.

Grain damage $(\%)=\frac{\text { Number of damaged grains }}{\text { Number of grains in sample }} \times 100$

Swelling capacity of the grains were determined using following equations as reported by Williams et al., (1983).

\section{Swelling capacity, $\mathrm{ml} /$ grain $=$}

Volume after soaking - Volume before soaking

\section{Number of grains}

Germination percentage was calculated by using the method given by International Seed Testing Association (ISTA, 1996). Seed vigour index was determined as reported by ISTA (1996) by using following formula:

Seed vigour index $=$ Average seedling length $($ root + shoot $)(\mathrm{cm}) \times$ Germination $(\%)$

Statistical analysis was carried out by Completely Randomized Design with three replications. All the treatments were compared at $5 \%$ level of significance using the critical difference test.

\section{Results and Discussion}

\section{Environmental parameters}

Maximum temperature $\left(38.5^{\circ} \mathrm{C}\right)$ was recorded in the month of May while minimum temperature $\left(13.2{ }^{\circ} \mathrm{C}\right)$ was observed in the month of January. Maximum RH was recorded in the month of July (91.1\%) while minimum RH was found in the month of March (18.8\%).

\section{Seed quality parameters of chickpea grains}

\section{Moisture content (\%)}

It is evident from Figure 1 that moisture content of the grain increased drastically for JB followed by JBL and PPL up to four months of storage period. However, little variation was observed in other treatments. The increase in moisture content of the grain up to four months (up to August) of storage period might be due to hygroscopic nature of the grain and moisture exchange in a pervious material during high $\mathrm{RH}$ in monsoon season (Harrington, 1972; Malarkodi, 1997; Roberts, 1986). The moisture content of the grain deceased after four months of storage period for all the treatments. The maximum moisture content of the chickpea stored in JB, JBL and PPL was found $12.38 \%, 10.39 \%$, and 10.12 $\%$, respectively on four months of storage. Minimum moisture content was observed in 
ALPEV followed by MCPV, HDPEV and PICS i.e. vacuum packaging and triple layer PICS bags during entire storage. It might be attributed to their lesser permeability in plastic packaging materials as well as vacuum packaging (Sumathi, 2010). The similar results for moisture content were also reported by Asha (2012) in maize, Kurdikeri et al., (1995) in maize and Shaw (1998) in green gram during storage.

\section{Insect population(number/500g)}

Insect was not observed up to two months of storage period in the chickpea grain. It is apparent from the Table 1 that the insect population of pulse beetle (Callosobruchus chinensis L.) was only found in jute bag. However, it started in JB on four months of storage and the insect population increased cumulative as storage progressed. i.e., 46 numbers $/ 500 \mathrm{~g}$ of sample at the end of twelve months of storage period. The increase in insect population in the grain might due to higher moisture content and aeration which enhanced grain deterioration (Monira et al., 2012). JBP, PPL, HDPEV, MCPV, ALPEV and PICS treatments were observed free from insect infestation throughout the storage period. It might be due to reduced pressure and resulting oxygen content interfered with insect movement, feeding and respiration (Adler et al., 2016). These findings are fairly matched with Haile (2015) in chickpea, Martin et al., (2015) in wheat and Baributsaet al., (2017) in chickpea grain.

\section{Grain damage (\%)}

Grain damage was not observed up to two months of storage period in the chickpea grain is presented in Table 2. From the table, it can be observed that the grain damage in JB increased with increase in storage period. Grain damage increased in the grain might be due to the insect infestation increased during storage. The JB was recorded the highest grain damage $(26.33 \%)$ at the end of storage period and thus found susceptible to pulse beetle. JBP, PPL, HDPEV, MCPV, ALPEV and PICS treatments were observed free from grain damage during entire storage period. Similar results for increase in grain damage were also reported by Sharma et al., (2007) in chickpea, Shaw (1998) in green gram Regmi and Dhoj (2013) in chickpea and Basavegowda and Arunkumar (2013) in chickpea.

\section{Swelling capacity}

It is obvious from Figure 2 that swelling capacity of chickpea grain decreased with increase in storage period. The effect of different packaging materials on swelling capacity was found significant during entire storage period. PPL resulted significantly highest swelling capacity $(0.248 \mathrm{ml} /$ grain $)$ at the end of storage period. However, JBP and JB were found at par with PPL during entire storage period. Swelling capacity of the grain was found minimum for ALPEV (0.117 $\mathrm{ml} /$ grain) and it was at par with MCPV throughout storage period. It might be due to formation of structural change and harder texture of pulse grain, increase in electric conductivity and solute leaching during storage which rendered the cells resistant to water absorption (Bressani, 1993 and Kilmer et al., 1994, Nasar-Abbas et al., 2008).

\section{Germination percentage}

It is evident from the Figure 3 that the germination of chickpea grain reduced with increase in storage period might be attributed to insect infestation and grain damage. The decline in germination percentage over the storage period irrespective of treatment was due to ageing effect leading to depletion of food reserves, seed deterioration, fluctuating temperature, relative humidity and grain moisture content as influenced by storage packaging materials (Kumar et al., 2007). 
Table.1 Effect of different packaging materials on insect population (number $/ 500 \mathrm{~g}$ ) of chickpea grain during storage

\begin{tabular}{|c|c|c|c|c|c|}
\hline \multirow[t]{2}{*}{ Treatment } & \multicolumn{5}{|c|}{ Storage period, Months } \\
\hline & 4 & 6 & 8 & 10 & 12 \\
\hline JB & $1.64 *(2.3)$ & $2.32 *(5.0)$ & $4.01 *(15.7)$ & $4.91 *(23.7)$ & $6.81 *(46.0)$ \\
\hline JBP & $0.71 *(0.0)$ & $0.71 *(0.0)$ & $0.71 *(0.0)$ & $0.71 *(0.0)$ & $0.71 *(0.0)$ \\
\hline PPL & $0.71 *(0.0)$ & $0.71 *(0.0)$ & $0.71 *(0.0)$ & $0.71 *(0.0)$ & $0.71 *(0.0)$ \\
\hline HDPEV & $0.71 *(0.0)$ & $0.71 *(0.0)$ & $0.71 *(0.0)$ & $0.71 *(0.0)$ & $0.71 *(0.0)$ \\
\hline MCPV & $0.71 *(0.0)$ & $0.71 *(0.0)$ & $0.71 *(0.0)$ & $0.71 *(0.0)$ & $0.71 *(0.0)$ \\
\hline ALPEV & $0.71 *(0.0)$ & $0.71 *(0.0)$ & $0.71 *(0.0)$ & $0.71 *(0.0)$ & $0.71 *(0.0)$ \\
\hline PICS & $0.71 *(0.0)$ & $0.71 *(0.0)$ & $0.71 *(0.0)$ & $0.71 *(0.0)$ & $0.71 *(0.0)$ \\
\hline S.Em. \pm & 0.099 & 0.095 & 0.082 & 0.079 & 0.106 \\
\hline C.D. at $5 \%$ & 0.299 & 0.288 & 0.249 & 0.238 & 0.322 \\
\hline C.V. \% & 20.290 & 17.520 & 12.060 & 10.410 & 11.630 \\
\hline
\end{tabular}

* Data subjected to square root transformation

Figures in parentheses are original values

Table.2 Effect of different packaging materials on grain damage (\%) of chickpea grain during storage

\begin{tabular}{|c|c|c|c|c|c|}
\hline \multirow[t]{2}{*}{ Treatment } & \multicolumn{5}{|c|}{ Storage period, Months } \\
\hline & 4 & 6 & 8 & 10 & 12 \\
\hline JB & $1.27 *(1.2)$ & $1.98 *(3.5)$ & $2.96 *(7.5)$ & $3.53 *(12.0)$ & $5.38 *(26.3)$ \\
\hline JBP & $0.71 *(0.0)$ & $0.71 *(0.0)$ & $0.71 *(0.0)$ & $0.71 *(0.0)$ & $0.71 *(0.0)$ \\
\hline PPL & $0.71 *(0.0)$ & $0.71 *(0.0)$ & $0.71 *(0.0)$ & $0.71 *(0.0)$ & $0.71 *(0.0)$ \\
\hline HDPEV & $0.71 *(0.0)$ & $0.71 *(0.0)$ & $0.71 *(0.0)$ & $0.71 *(0.0)$ & $0.71 *(0.0)$ \\
\hline MCPV & $0.71 *(0.0)$ & $0.71 *(0.0)$ & $0.71 *(0.0)$ & $0.71 *(0.0)$ & $0.71 *(0.0)$ \\
\hline ALPEV & $0.71 *(0.0)$ & $0.71 *(0.0)$ & $0.71 *(0.0)$ & $0.71 *(0.0)$ & $0.71 *(0.0)$ \\
\hline PICS & $0.71 *(0.0)$ & $0.71 *(0.0)$ & $0.71 *(0.0)$ & $0.71 *(0.0)$ & $0.71 *(0.0)$ \\
\hline S.Em. \pm & 0.064 & 0.084 & 0.050 & 0.057 & 0.044 \\
\hline C.D. at $5 \%$ & 0.194 & 0.253 & 0.152 & 0.172 & 0.134 \\
\hline C.V. \% & 14.07 & 16.28 & 8.61 & 8.82 & 5.7 \\
\hline
\end{tabular}

* Data subjected to square root transformation

Figures in parentheses are original values 
Fig.1 Effect of different packaging materials on moisture content of chickpea grain

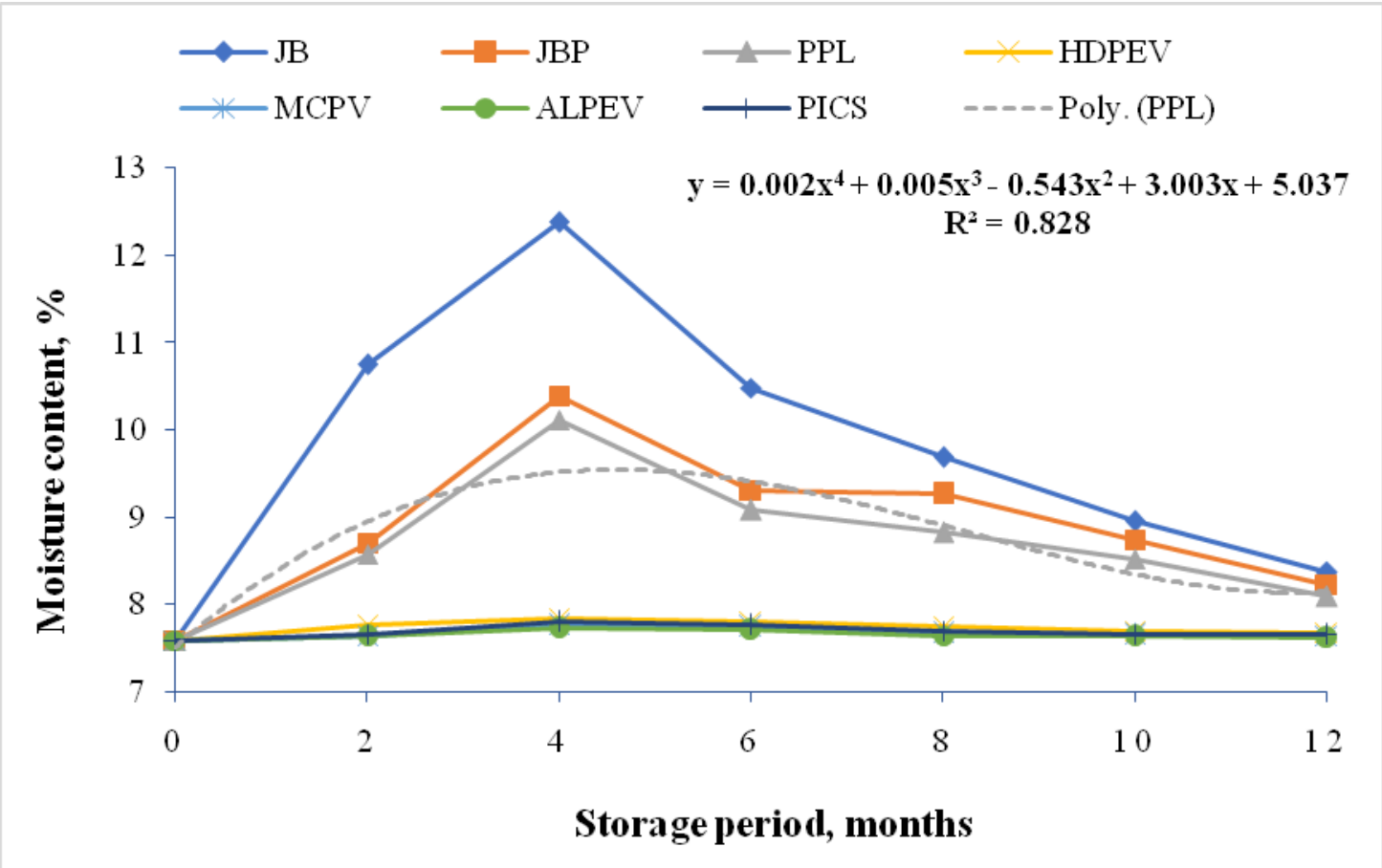

Fig.2 Effect of different packaging materials on swelling capacity of chickpea grain

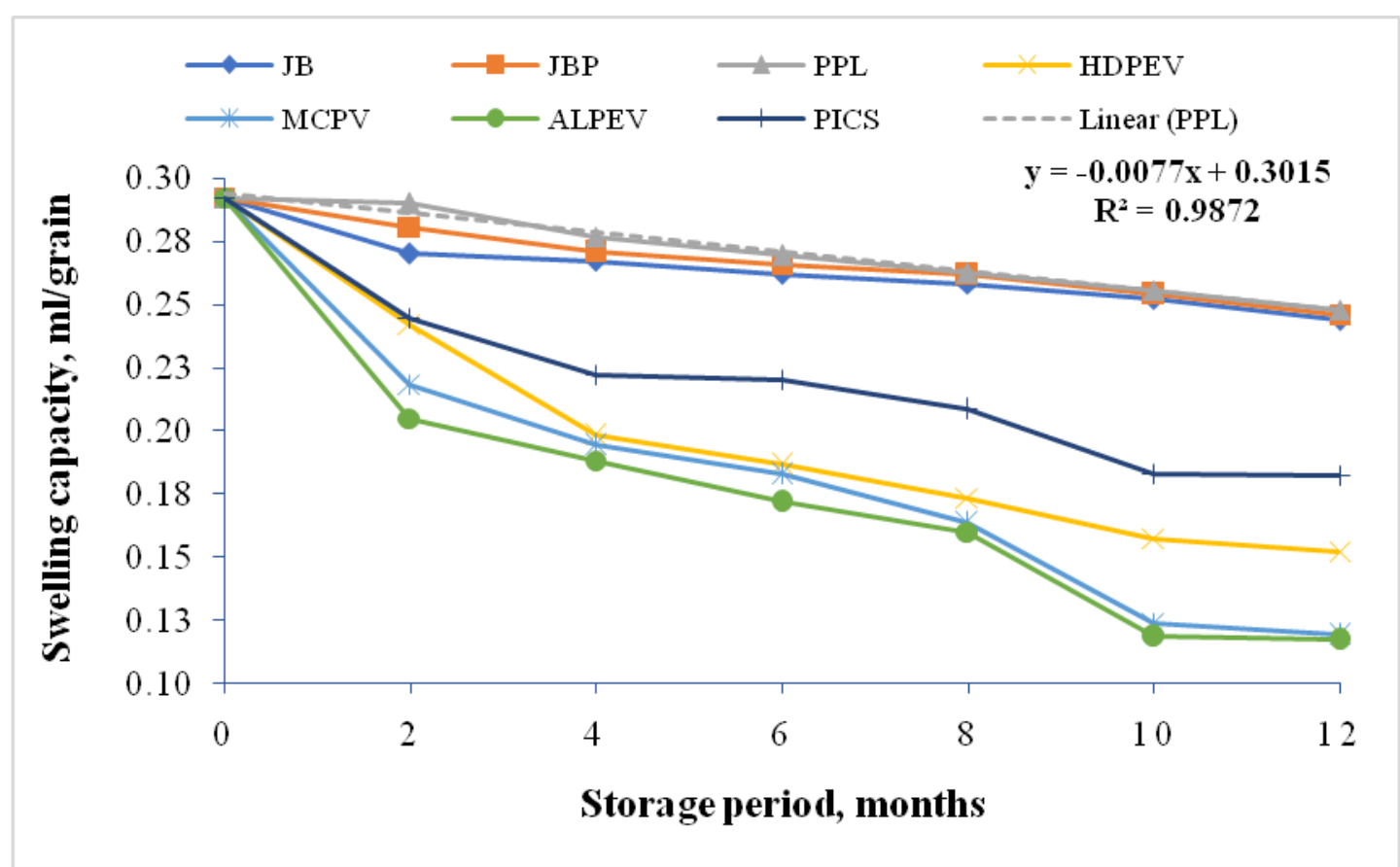


Fig.3 Effect of different packaging materials on germination of chickpea grain

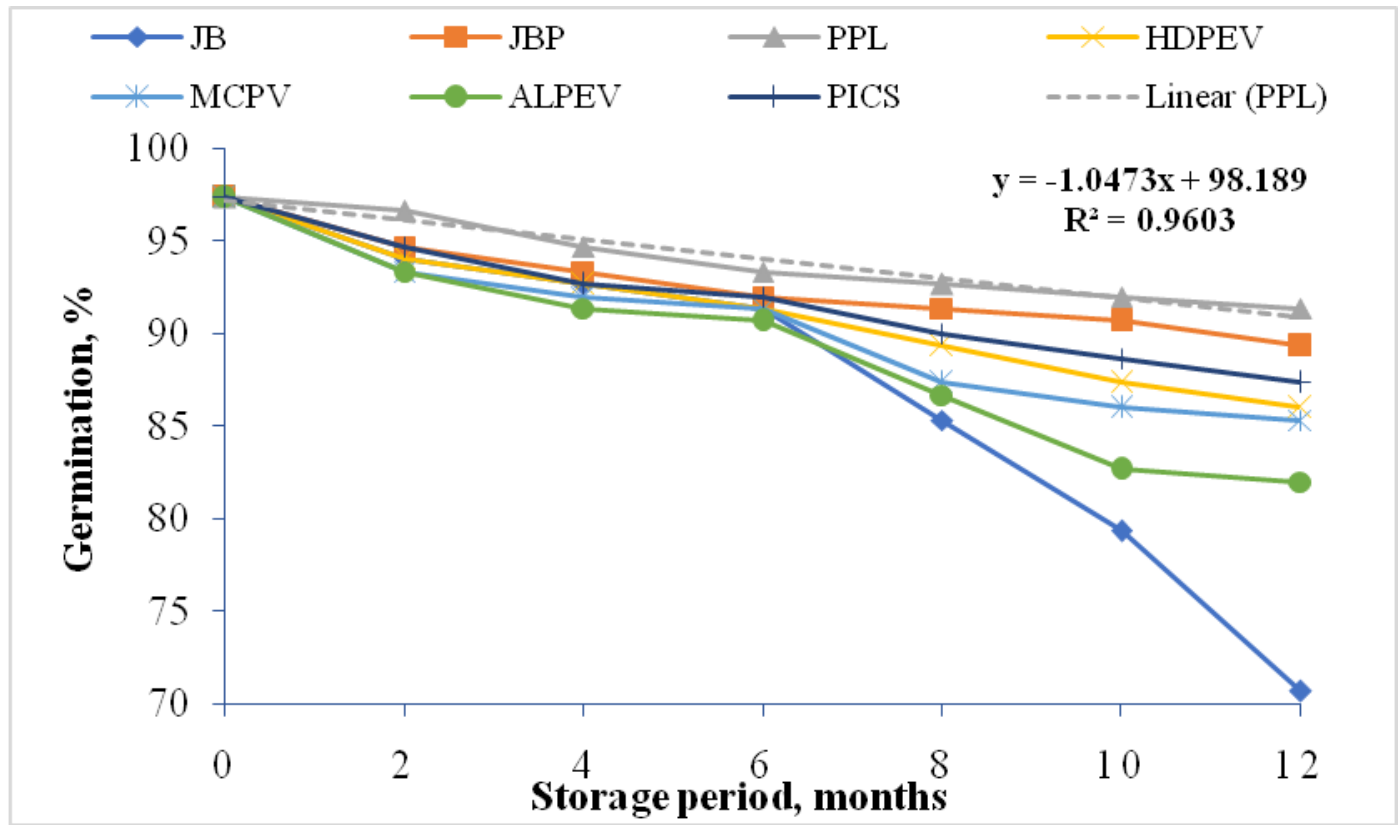

Fig.4 Effect of different packaging materials on seed vigour index of chickpea grain

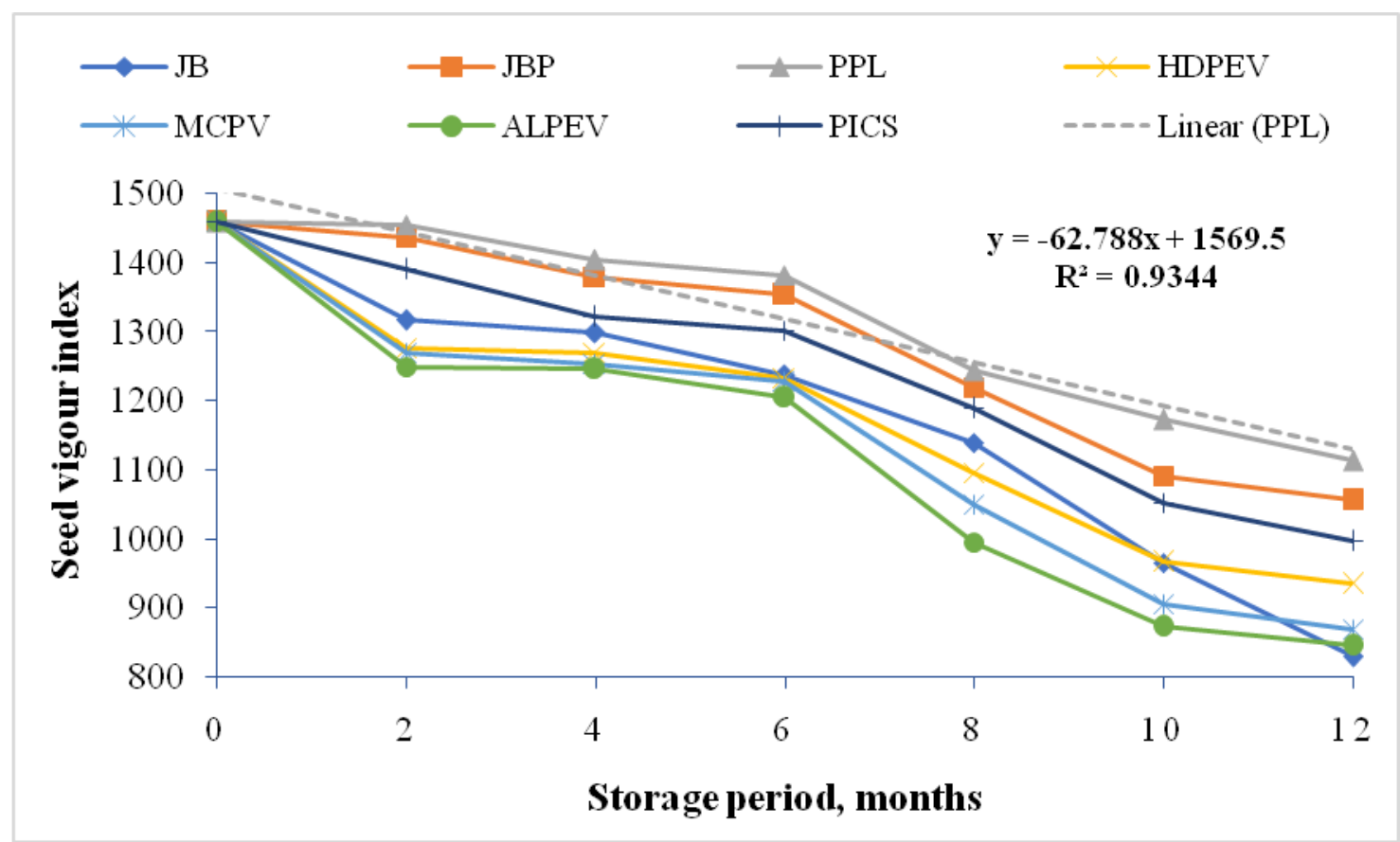


The initial germination of the grain was observed $97.33 \%$ before packaging and storage. Maximum germination was recorded in PPL (91.33 \%) followed by $\operatorname{JBP}(89.33 \%)$ and PICS $(87.33 \%)$ at the end of storage period. Germination of the grain for HDPEV, MCPV and ALPEV was found $86.00 \%$, $85.33 \%$ and $82.00 \%$, respectively. Minimum germination was recorded in JB $(70.67 \%)$ at the end of storage period. The decrease in germination during storage was also reported by Mookherjee et al., (1970) in chickpea, and Jagtap (2006) in sorghum.

\section{Seed vigour index}

Seed vigour index declined with increase in storage period irrespective of packaging materials (Fig. 4). It might be due to changes in free radical scavenging enzymes, increase in free radical production, degradation of protein and DNA, increase in amino acid pool for reduction in vigour and viability during ageing (McDonald, 2004). Significantly highest seed vigour index was recorded in chickpea grain stored in PPL (1114) followed by JBP (1056) at the end of storage period. Seed vigour index for PICS, HDPEV, MCPV and ALPEV was found 996, 935, 869 and 846, respectively. Minimum seed vigour index was recorded by JB (829) at the end of twelve months of storage. The results of present study are in agreement with Chormule et al., (2015) in chickpea, Meena et al., (2017) in cotton and Naguib et al., (2011) in wheat.

From the results, it may be concluded that JBP, PPL, HDPEV, MCPV, ALPEV and PICS were found to be the best over the jute bag which did not contain insect population and grain damage during entire storage period. Vacuum packed materials viz., ALPEV, MCPV and HDPEV had minimum moisture content, germination and seed vigour index of chickpea grain. Maximum moisture content, insect population and grain damage as well as minimum germination and seed vigour index of the grain was recorded in jute bag. Considering the overall aspects of the study, it may be concluded that PPL was observed to be best packaging material amongst all treatments having highest swelling capacity, germination and seed vigour index, no insect population, no grain damage and moderate moisture content of chickpea grain for twelve months of storage.

\section{References}

Adler, C. S., Ndomo, M. A. F., Begemann, J. and Munzing, K. 2016. Effect of vacuum storage of wheat (Triticum aestivum) grain on the granary weevil, Sitophilus granarius and wheat quality. In: Proceedings of the 10th International Conference on Controlled Atmosphere and Fumigation in Stored Products (CAF2016), CAF Permanent Committee Secretariat, Winninpeg, Canada. pp. 287-290.

Anonymous, 2017a. Agricultural statistics at a glance. Directorate of Economics and Statistics. Indian Crop Research Institute, Government of India, New Delhi. p. 12.

Asha, A. M. 2012. Effect of plant products and containers on storage potential of maize hybrid. M.Sc. (Agri.) Thesis. University of Agricultural Sciences, Dharwad. Karnataka, India.

Baributsa, D., Baoua, I. B., Bakoye, O. N., Amadou, L. and Murdock, L. L. 2017. PICS bags safely store unshelled and shelled groundnuts in Niger. Journal of Stored Products Research. 72: 54-58.

Basavegowda, G. S. and Arunkumar, H. 2013. Effect of commercial cold storage conditions and packaging materials on seed quality of chickpea (Cicer Arietinum. L). Glob. J. Sci. Front. Res. Agric. Vet. Sci. 13(2): 22-26. 
Bressani, R. 1993. Grain quality of common beans. Food Reviews International. 9(2): 237-297.

Chahal, S. S. 2011. Scientific grain storage system for curbing food wastage. The National Agric. Magazine. 14(1): 23-24.

Chormule, S. R., Bhatiya, V. J., Babariya, C. A. and Abhinandan, S. P. 2015. Effect of storage periods on quality of chickpea (Cicer arietinum L.). In: Conference on enhancement of crop productivity through physiological interventions, at N. M. College of Agriculture, Navsari Agricultural University, Navsari. Vol.: 5.

Haile, A. 2015. Eco-friendly management of chickpea storage pest, Callosobruchus Chinensis L. (Coleoptera; Bruchidae) under laboratory conditions in Eritrea. Journal of Stored Products and Postharvest Research. 6(8): 66-71.

Harrington, J. F. 1972. Seed storage and longevity. In: Seed biology. Academic Press, New York and London. 3: 145245.

ISTA. 1996. International Rules for Seed Testing. Vol. 24, International Seed Testing Association, Zurich, Switzerland.

Jagtap, K. B. 2006. Effect of packaging materials on seed quality of sorghum cultivars [Sorghum bicolor (L.) Moench] during ambient storage condition. M.Sc. (Agri.) thesis. Seed technology. Mahatma Phule Krishi Vidyapeeth, Rahuri.

Jukanti, A. K., Gaur, P. M., Gowda, C. L. L. and Chibbar, R. N. 2012. Nutritional quality and health benefits of chickpea (Cicer arietinum L.): a review. British Journal of Nutrition. 108(1): 11-26.

Kilmer, O. L., Seib, P. A. and Hoseney, R. C. 1994. Effects of minerals and apparent phytase activity in the development of the hard-to-cook state of beans. Cereal Chemistry. 71(5): 476-482.
Kumar, J., Nisar, K., Arunkumar, M. B., Walia, S., Shakil, N. A., Prasad, R. and Parmar, B. S. 2007. Development of polymeric seed coats for seed quality enhancement of soybean (Glycine max). Indian Journal of Agricultural Science. 77(11): 738-743.

Kurdikeri, M. B., Aswathaiah, B., Rajendraprasad, S. and Aswathnaryyan, S. C. 1995. Storability of maize hybrids under ambient conditions of Bangalore. Seed Research. 23: 121-124.

Malarkodi, K. 1997. Halogenation to control seed deterioration in pearl millet (Pennisetum glaucum L.). M.Sc. Agri. Thesis. Tamil Nadu Agricultural University, Coimbatore.

Martin, D. T., Baributsa, D., Huesing, J. E., Williams, S. B. and Murdock, L. L. 2015. PICS bags protect wheat grain, Triticum aestivum L., against rice weevil, Sitophilus oryzae L. (Coleoptera: Curculionidae). Journal of Stored Products Research. 63: 22-30.

McDonald, M. B. 2004. Orthodox seed deterioration and its repair. Handbook of Seed Physiology: Applications to Agriculture, Benech-Arnold, RL and RA Sanchez (Eds.). Food Products Press, New York, London. pp. 273-304.

Meena, M. K., Chetti, M. B. and Nawalagatti, C. M. 2017. Influence of vacuum packaging and storage conditions on the seed quality of cotton (Gossypium spp.). Int. J. Pure App. Biosci. 5(1): 789-797.

Modgil, R. and Mehta, U. 1994. Effects of Different levels of Callosobruchus chinensisL. infestation on proximate principles, true protein, methionine anduric acid contents of green gram and red gram. Journal Food Sci. Technol.31(21): 135-137.

Monira, U. S., Amin, M. H. A., Aktar, M. M. and Mamun, M. A. A. 2012. Effect of containers on seed quality of storage soybean seed. Bangladesh Research 
Publications Journal. 7(4): 421-427.

Mookherjee, P. B., Jotwani, M. G., Yadav, T. D. and Sircar, P. 1970. Studies on incidence and extent of damage due to insect pests in stored seeds-II. Leguminous and vegetable seeds. Indian Journal of Entomology. 32(4): 350-355.

Naguib, N. A., Mohamed, E. A. and El-Aidy, N. A. 2011. Effect of storage period and packaging material on wheat (Triticum aestivum L.) Seed viability and quality. Egypt. J. Agric. Res. 89(4): 1481-1496.

Nasar-Abbas, S. M., Plummer, J. A., Siddique, K. H. M., White, P., Harris, D. and Dods, K. 2008. Cooking quality of faba bean after storage at high temperature and the role of lignins and other phenolics in bean hardening. LWT- Food Sci. Technol., 42: 17031711.

Regmi, H. and Dhoj, Y. 2013. Eco-friendly management of pulse beetle. Journal of Agriculture and Environment. 12: 8190.

Roberts, E. H. 1986. Quantifying Seed deterioration. In: Physiology of Seed Deterioration. Crop Science Society of America: Madison. pp. 101-123.

Sadasivam, S. and Manickam, A. 1996.
Biochemical Methods for Agriculture Sciences, Willey Eastern Limited, New Delhi.

Sharma, R., Verma, R. A. and Bhol, B. P. 2007. Effect of different storage structures on the infestation of pulse beetle in chickpea grain. Indian Journal of Entomology. 69(3): 241.

Shaw, K. K. 1998. Some quantitative and qualitative effects on green gram stored under conditions of different initial grain moisture contents, storage periods and storage containers. Journal of the Agricultural Science Society of North East India. 11(1): 61-65.

Sumathi, S. 2010. Studies on seed production, post-harvest handling and seed testing in karpokkarasi (Psoralea corylifolia L.). Ph.D. Thesis. Tamil Nadu Agricultural University, Coimbatore, India.

Taylor, R. W. D. 1989. Phosphine a major fumigant at risk. International Pest Control. 31(1): 10-14.

Williams, P. C., Nakoul, H. and Singh, K. B. 1983. Relationship between cooking time and some physical characteristics in chickpeas (Cicer arietinum L.). Journal of the Science of Food and Agriculture. 34(5): 492-496.

\section{How to cite this article:}

Jay V. Patel, D.K. Antala and Abhay N. Dalsaniya. 2018. Influence of Different Packaging Materials on the Seed Quality Parameters of Chickpea. Int.J.Curr.Microbiol.App.Sci. 7(12): 2458-2467. doi: https://doi.org/10.20546/ijcmas.2018.712.279 